\title{
Interprestasi Data Anomali Medan Magnetik Total Transformasi Reduksi ke Kutub di Laut Flores
}

Eny Rohyati ${ }^{*}$, Catur Purwanto ${ }^{\mathrm{b}}$, Yudha Armanª, Apriansyahc

\author{
aProdi Fisika, FMIPA Universitas Tanjungpura, Pontianak \\ bPusat Penelitian dan Pengembangan Geologi Kelautan, Bandung \\ cProdi Ilmu Kelautan, FMIPA Universitas Tanjungpura, Pontianak \\ *Email : eny.rohyati@student.untan.ac.id
}

\begin{abstract}
Abstrak
Penelitian dengan menggunakan metode magnetik di laut Flores telah dilakukan. Data medan magnet total diukur menggunakan Proton Precision Magnetometer (PPM) dan kapal Geomarin III dengan jumlah lintasan yaitu sebanyak 20 lintasan. Data anomali medan magnetik total selanjutnya dilakukan koreksi diurnal dan koreksi IGRF (International Geomagnetic Reference Field) untuk menghasilkan data intensitas anomali medan magnetik total. Data anomali magnetik total selanjutnya ditransformasi reduksi ke kutub. Pola kontur intensitas anomali medan magnetik total hasil reduksi ke kutub digunakan untuk mengidentifikasi struktur bawah permukaan Laut Flores. Berdasarkan peta kontur anomali medan magnetik total dilokasi penelitian secara umum terdistribusi antara -156.1 nT sampai $321.9 \mathrm{nT}$. Anomali rendah -156.1 nT sampai 0 cenderung mengikuti titik pengukuran yang berdekatan dengan adanya indikasi gunung api bawah laut di lokasi penelitian.
\end{abstract}

Kata Kunci : metode magnetik, anomali medan magnet total, reduksi ke kutub, laut flores

\section{Latar Belakang}

Metode magnetik merupakan salah satu metode geofisika yang memanfaatkan medan alami yang dihasilkan bumi dalam pengukurannya. Metode magnetik telah diaplikasikan untuk kajian pemetaan, struktur patahan dan eksplorasi panas bumi. Metode magnetik memiliki kelebihan di antaranya adalah proses akuisisi data dan koreksi data magnetik relatif mudah. Akan tetapi, metode magnetik memiliki kekurangan seperti rumitnya melakukan interpretasi kualitatif data magnetik yang disebabkan oleh sifat medan magnetik yang dipole [1]. Sifat medan magnetik yang dipole menyebabkan data magnetik memiliki banyak penafsiran sehingga interpretasi data sulit dilakukan, terlebih untuk daerah penelitian yang berada pada daerah lintang magnetik rendah. Oleh karena itu, diperlukan metode pengolahan data tingkat lanjut untuk mengurangi pengaruh medan magnet bumi yang dipole dan mempermudah interpretasi kualitatif data magnetik.

Salah satu metode yang dapat digunakan adalah metode transformasi reduksi ke kutub (Reduction to Pole). Hasil dari reduksi ke kutub menunjukkan anomali magnetik yang bersifat monopol. Pada transformasi ke kutub, benda anomali berada tepat di bawah kurva yang memiliki nilai anomali magnetik tertinggi. Metode transformasi reduksi ke kutub telah banyak digunakan dalam kajian geofisika, antara lain; eksplorasi panas bumi [2] dan pemetaan teluk[3]. Penelitian ini dilakukan untuk mengidentifikasi benda anomali magnetik dan sebarannya berdasarkan pola kontur intensitas anomali medan magnetik total hasil transformasi reduksi ke kutub.

\section{Metodologi}

Data yang digunakan dalam penelitian ini adalah data sekunder berupa data intensitas medan magnet yang diperoleh dari Pusat Penelitian dan Pengembangan Geologi Kelautan (PPPGL) Bandung pada bulan Mei 2012 di Laut Flores. Akuisisi data magnetik dilakukan sebanyak 20 lintasan. Secara geografis lokasi penelitian terletak pada koordinat $121^{\circ} 30^{\prime} 00^{\prime \prime}$ $123^{\circ} 00^{\prime} 00^{\prime \prime}$ BT dan $06^{\circ} 00^{\prime} 00^{\prime \prime}-08^{\circ} 00^{\prime} 00^{\prime \prime}$ LS.

Tahapan yang dilakukan dalam penelitian ini meliputi studi literatur, input data, pengolahan data dan interpretasi data. Tahapan pengolahan data terdiri atas pengolahan data intensitas medan magnetik total terukur di Laut flores. Data yang terukur saat proses akuisisi data adalah data intensitas medan magnetik total. Data intensitas medan magnetik dilakukan koreksi International Geomagnetic Reference Field dan koreksi diurnal. Data IGRF diperoleh dengan memasukan koordinat lokasi penelitian dan tanggal penelitian pada laman website https://www.ngdc.noaa.gov/geomag/calculator. Sedangkan data variasi harian dapat diunduh di laman website http://www.intermagnet.org. setelah dilakukan proses koreksi tersebut maka akan didapatkan intensitas anomali medan 
magnetik total. Data intensitas anomali medan magnetik total selanjutnya ditransformasi reduksi ke kutub sehingga menghasilkan intensitas anomali medan magnetik total hasil transformasi reduksi ke kutub. Data intensitas anomali medan magnetik total hasil transformasi reduksi ke kutub selanjutnya diplotkan dengan menggunakan Software Oasis Montaj dan didapatkan peta kontur intensitas anomali medan magnetik total hasil transformasi reduksi ke kutub. Peta kontur intensitas anomali medan magnetik total hasil transformasi reduksi ke kutub digunakan untuk proses interpretasi data. Proses interpretasi data dilakukan dengan melihat pola kontur intensitas anomali magnetik total transformasi reduksi ke kutub.

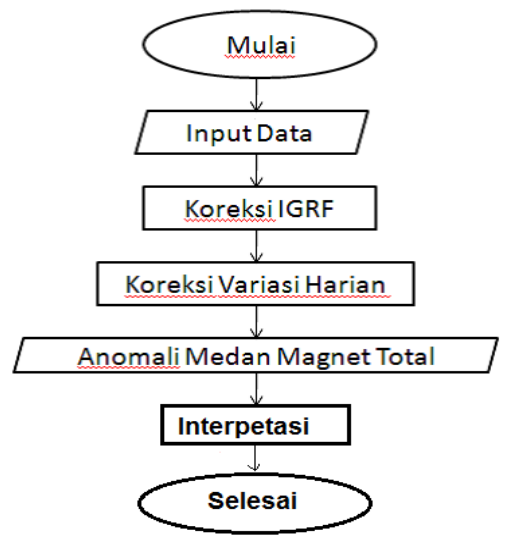

Gambar 1. Diagram alir penelitian

\section{Hasil dan Pembahasan}

Survei metode magnetik dilakukan dengan mengukur medan alami yang dipancarkan oleh bumi, dan medan alami yang dimaksud dalam pembahasan ini ialah medan magnetik. Survei magnetik pada penelitian ini dilakukan oleh Tim PPPGL (Pusat Penelitian dan Pengembangan Geologi Kelautan) Bandung di Laut Flores. Adapun analisis data didasarkan pada interpretasi kualitatif. Interpretasi kualitatif dilakukan untuk menunjukan keberadaan peta kontur medan magnet total, serta kontur anomali medan magnet total yang sudah ditransformasi sebagai salah satu informasi dalam menentukan titik - titik penyebab anomali di lokasi pengukuran berdasarkan klosur konturnya. Sebagaimana diketahui bahwa distribusi nilai medan magnet total merupakan hasil pengukuran langsung dengan Proton Precision Magnetometer (PPM) dan kapal Geomarin III di lokasi pegukuran, dan distribusi anomali medan magnet sebagai hasil dari pengolahan data pengukuran yang akan ditampilkan dalam bentuk peta kontur.

\section{Medan magnetik total di Laut Flores}

Medan magnetik total merupakan distribusi nilai hasil pengukuran magnetik yang belum dikoreksi variasi harian maupun IGRF. Variasi harian merupakan variasi perubahan yang relatif cepat berkaitan dengan waktu dan bulan. Koreksi IGRF merupakan koreksi yang dilakukan terhadap data medan magnet terukur untuk menghilangkan pengaruh medan magnet utama bumi. Interntional Geomagnetics Reference Field (IGRF) merupakan nilai standar intensitas medan magnet utama bumi yang dijadikan referensi nilai magnet di suatu tempat. Distirbusi medan magnetik total di lokasi penelitian dikonturkan menggunakan aplikasi oasis montaj. Gambar 2. Menunjukkan sebaran intensitas medan magnet di Laut Flores yang telah dilakukan transformasi reduksi ke kutub.

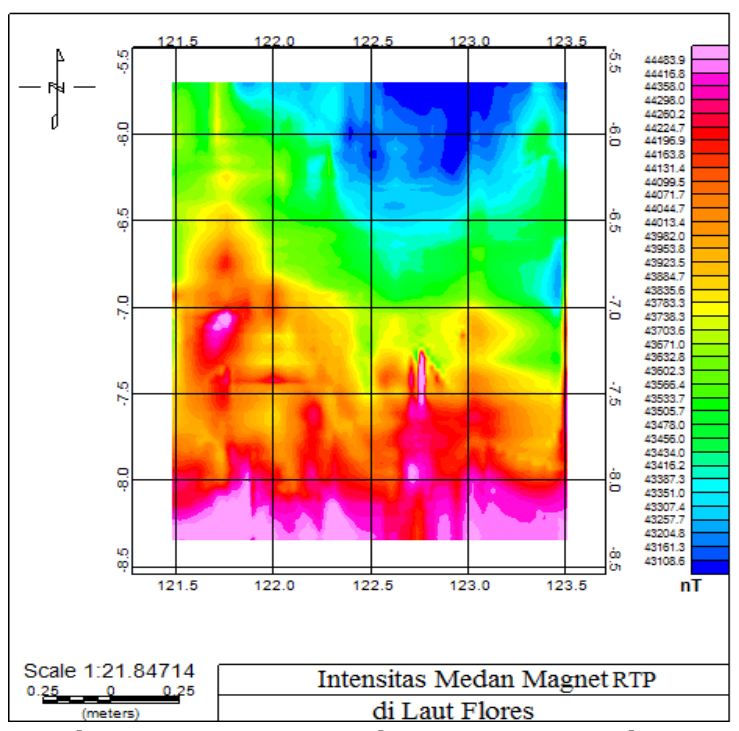

Gambar 2. Intensitas Medan Magnet RTP di Laut Flores.

Intensitas medan magnet total bumi berkisar antara $25.000 \mathrm{nT}-65.000 \mathrm{nT}$, dan untuk wilayah Indonesia yang terletak di utara ekuator mempunyai intensitas $\pm 40.000 \mathrm{nT}$ sedangkan di selatan ekuator \pm 45.000 nT [4]. Berdasarkan Gambar 2 menunjukkan data intensitas medan magnet total di area penelitian antara $43108.6 \mathrm{nT}$ sampai 44483.9 nT. Intensitas 43738 nT sampai 44298.0 nT hampir secara umum mendominasi area pengukuran, dan terdapat beberapa titik memiliki kisaran medan magnet antara 43180.6 nT sampai 43703.6 nT serta beberapa titik ukur dengan variasi yang cenderung tinggi yakni antara $44358.0 \mathrm{nT}$ sampai $44483.9 \mathrm{nT}$ pada bagian selatan daerah penelitian, adanya variasi data medan magnet di area pengukuran tersebut dipengaruhi oleh medan utama magnet bumi (IGRF) yang ikut terbaca oleh magnetometer. 


\section{Anomali Medan magnetik total di Laut} Flores

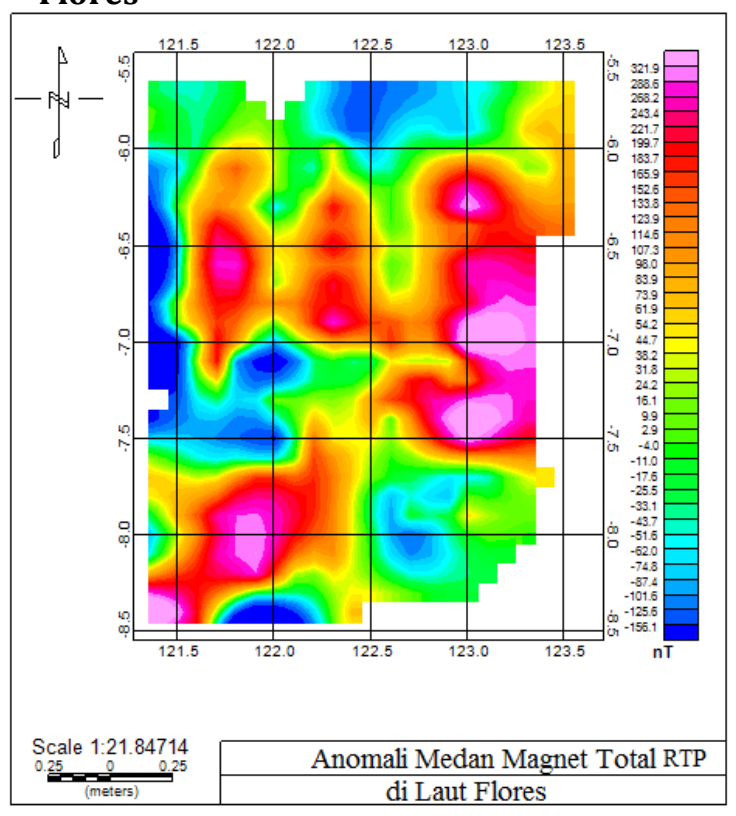

Gambar 3. Anomali Medan Magnet Total RTP di Laut Flores.

Data medan magnet yang merupakan hasil koreksi variasi harian dan koreksi IGRF disebut anomali medan magnet total. Nilai anomali total magnet total tersebut kemudian diplot untuk melihat distribusi anomali magnet di lokasi penelitian. Kontur anomali magnet total sebagaimana pada Gambar 3, menunjukkan adanya sebarananomali medan magnet positif dan negatif. Tanda positif dan negative mengindikasikan kuat dan rendahnya nilai anomali magnet pada lokasi pengukuran. Kisaran anomali yang terukur yaitu -156.1 nT sampai dengan 321.9 nT yang mengartikan bahwa variasi anomali rendah adalah -156.1 nT (negatif) dan nilai anomali medan magnet tinggi adalah 321.9 nT (positif). Dengan demikian nilai medan magnet hasil pengukuran menggunakan magnetometer tersebut harus dikoreksi terhadap variasi waktu maupun IGRF sehingga pada akhirnya data medan magnet yang diperoleh nantinya adalah benar benar akibat dari induksi batuan yang disebabkan oleh adanya gunung api bawah laut dilokasi penelitian.

Distribusi anomali medan magnet rendah yang memiliki nialai anomali antara -156 nT sampai $0 \mathrm{nT}$ melingkupi daerah penelitian. Sedangkan anomali tinggi berada di bagian timur dan barat daya penelitian. Dari gambaran kontur anomali medan magnet total yang diperoleh di lokasi penelitian (Gambar 3, diketahui sebaran anomali magnet negatif mengikuti titik-titik ukur yang berdekatan dengan pulau Kalaotoa. Daerah penelitian merupakan daerah yang aktif secara tektonik dan vulkanisme tidak aktif dan sesar-sesar aktif. Sesar naik sebagai bagian dari Zona Anjakan Busur Belakang Flores dijumpai di bagian selatan Pulau Kalaotoa yang terbentuk Pliosen Bawah dan aktivitas pembentukkan gunungapi sebagai busur magma tunggal di utara PulauFlores terjadi mulai Plistosen Bawah. Akibat adanya Komplek Batuan Gunungapi di bagian utara Pulau Flores. Pada bagian utara penelitian terlihat perbedaan kontran dari klosur anomali tinggi ke rendah di sekitar pulau batuata. Berdasarkan informasi geologi menunjukkan bahwa Gunungapi bawah laut yang berada di bagian utara Pulau Flores diperkirakan adalah gunung api bawah laut yang diperlihatkan oleh adanya sesar normal yang membundar mengelilingi pulau batuata. Gunungapi bawah laut tersebut membentuk daerah rendahan yang berasosiasi dengan sesar normal yang berarah relatif timurlaut-baratdaya [5].

\section{Kesimpulan}

Berdasarkan penelitian yang telah dilakukan dapat disimpulkan bahwa ditribusi anomali medan magnet total di Laut Flores secara umum berada antara 156.1 nT sampai 321.9 nT. Anomali medan negatif terdistribusi mengikuti titik - titik ukur yang berdekatan dengan adanya indikasi gunung api bawah laut.

\section{Ucapan Terimakasih}

Terimakasih kepada Pusat Penelitian dan Pengembangan Geologi Kelautan (PPPGL) Bandung, yang telah memberikan izin melakukan Kerja Praktek sekaligus Tugas Akhir. Terimakasih kepada Bapak Adam dan Bapak Zulfikar yang telah bersedia menjadi pembimbing lapangan.

\section{Daftar Pustaka}

[1] Blakely, 1995. Potential Theory in Gravity and Magnetic Applications, Cambridge University Press. USA.

[2] Indratmoko, P., Nurwidyanto M. I., dan Yulianto T. 2009. Interpretasi Bawah Permukaan Daerah Manifestasi Panas Bumi Parang Tritis Kabupaten Bantul DIY dengan Metode Magnetik. Jurnal Berkala Fisika. Vol. 12, No. 4 (1410-9662): 153-160.

[3] Rahmad, B dan Ilahude, D. 2011. Pola Anomali Magnet dan Nilai Susceptibilitas dari Batuan Dasar Pada Pemetaan Geologi dan Geofisika di Perairan Teluk Bone Sulawesi Selatan. Jurnal Geologi Kelautan. Vol. 9. No. 13: 13-22. 
[4] Wahyudi, 2001. Panduan Workhsop Eksplorasi Geofisika (Teori dan Aplikasi), Lab. Geofisika FMIPA UGM. Yogyakarta.

[5] Rahardiawan, dan Purwanto,C., 2014, Struktur Geologi Laut Flores, Nusa Tenggara Timur, j.geologi kelautan., 12:165-178 